\title{
Reading History Forward
}

Jørgen Møller, Aarhus University, Denmark

ABSTRACT Recent decades have seen a productive methodological debate about how political scientists "do history." However, on one important point, the discussion has been surprisingly thin. This concerns the problem of reading history backward rather than forward. To understand this problem, we need to embed it in broader methodological discussions of how the selection of evidence is shaped (and potentially biased) by all sorts of prior assumptions going into the evidence-collection process. Thus, reading history backward makes scholars refrain from posing certain questions, become blind to certain descriptive developments and explanatory factors, and fail to enlist certain historical data. This article pulls together the fragmentary insights about this problem and devises an alternative, prospective approach centered on an open reading of the work of historians. Although this is a "low-tech" issue, it is one that has huge ramifications for the way we do historical analysis as political scientists.

"It is hard not to read the script backwards."

Greengrass $(2014,77)$

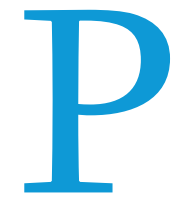

olitical scientists increasingly "go historical" to understand the origins of political and administrative institutions, which are used to explain other developments such as economic growth and democratization (Capoccia and Ziblatt 2010; Mahoney and Thelen 2015). Since the 1980s, the discipline has seen a number of highly productive methodological debates about how to do historical analysis (Bartolini 1993; Capoccia and Ziblatt 2010; Coppedge 2012, ch. 5; Kreuzer 2010; Lustick 1996; Møller and Skaaning 2018; Sewell 1996; Skocpol and Somers 1980; Tilly 1984). However, on one important point, the discussion has been surprisingly fragmented and thin. This concerns the problem of reading history backward, or what also is known as "presentism" or the fallacy of nunc pro tunc ("now for then") "in which the antecedent in a narrative series is falsified by being defined or interpreted in terms of the consequent" (Capoccia and Ziblatt 2010, 939; Fischer 1970, 135; Tilly 1975, 14-15).

The general problem can be defined as follows: reading history backward imposes a cognitive bias in which knowledge of an outcome leads to a one-sided selection of evidence and causal antecedents that support and help to explain the outcome. By definition, this leads scholars to ignore disconfirming and confounding causal antecedents. ${ }^{2}$ This problem is part of the larger

Jørgen Møller (Dis professor of political science at Aarhus University, Denmark. He can be reached at jm@ps.au.dk. phenomenon-emphasized by cognitive psychologists, sociologists of history, and historians of science-that a wide range of priors shapes our analysis and what ultimately constitutes evidence. A good example is hindsight bias, which is related to reading history backward. It imposes a creeping determinism on the past by making bygone events more predictable than they actually were when they took place, in the process distorting our memory of these events (Fischhoff 1975). Thus, we sort empirical evidence via cognitive and ontological filters that predispose us to arrive at certain interpretations. This presents a dilemma: on the one hand, such filters are necessary to avoid drowning in the complexity of the social world; on the other hand, if we adhere to them too closely, we misrepresent the empirical objects that we study.

Whereas reading history backward comes naturally to political scientists who delve into history with a particular explanatory purpose, it creates a number of problems. One particular complication has long been recognized. As Capoccia and Ziblatt (2010, 939) state, scholars who read history backward are apt to impute the causes of certain developments from their correlates or, in the functional version, their consequences (see also Pierson 2000). However, the problematic implications are much wider. This article identifies three additional problems of reading history backward. First, it makes explanations more deterministic by either freezing history or making history efficient. Second, it shapes how we describe past historical processes and the concepts we use to analyze these processes. Third, it affects the very questions that we pose about the past.

The purposes of this article are to (1) pull together the fragmentary insights about how to avoid that the very reason we are 
interested in the past colors the reading of the historical evidence; and (2) place these insights in a broader methodological context centered on selection bias (Lustick 1996). The article is structured as follows. First, the problems associated with reading history backward are further substantiated. Second, the article outlines and endorses an alternative, more open approach (i.e., reading history forward). Throughout the discussion, I draw on examples from the online appendix to illustrate the arguments.

\section{READING HISTORY BACKWARD}

The most egregious example of reading history backward in recent research is arguably the many large- $\mathrm{N}$ studies that analyze the period after 1945 but project their findings backward in time in problematic ways, thereby introducing selection bias. For redeployment." Making history efficient leads scholars to ignore the behavioral realities of often-contingent microprocesses (March and Olsen 1983, 737). These notions of history easily rule out counterfactual thinking and instead tend to infuse the analysis with the creeping determinism that also is associated with hindsight bias (Fischhoff 1975).

This shapes the theoretical lens by privileging functional or structural explanations at the expense of more contingent, actorcentered explanations. The previous example, centered on the Ghent effect, is one illustration. The online appendix shows how a larger body of research on the rise and development of medieval representative institutions or parliaments-including previous work by this author-has viewed this outcome as resting on an equilibrium characterized by a relatively even balance of power

\section{This problem is part of the larger phenomenon-emphasized by cognitive psychologists, sociologists of history, and historians of science-that a wide range of priors shapes our analysis and what ultimately constitutes evidence.}

instance, Rasmussen and Pontusson $(2017,28)$ note how most quantitative studies of the "Ghent effect"-that is, the notion that a Ghent system of unemployment insurance (as opposed to a stateadministered system) increases union density-read "history backwards." The Ghent effect is based on findings from studies that analyze the post-1960 period, which show that countries with Ghent systems have higher union density. This, in turn, has been used to infer that Left parties were behind creating Ghent systems before World War II. However, enlisting new data that go back to 1900, Rasmussen and Pontusson (2017) show that Ghent systems had no effect on unionization rates and that the Ghent effect instead is a result of increasing state subsidization in the decades after 1945. Furthermore, they argue that it was Social Liberal parties that favored Ghent systems, whereas genuine Left parties (i.e., Social Democrats) normally opted for state-administered unemployment insurance before World War II (see the online appendix for two additional examples).

Rasmussen and Pontusson's (2017) criticism of earlier research on the Ghent effect illustrates how scholars who read history backward become predisposed to overlooking confounding factors, thereby making their explanations too deterministic (Capoccia and Ziblatt 2010, 939; Pierson 2000). More particularly, retrospective inquiry risks imputing the causes that explain the advent of institutions from those that explain their later consolidation (Boucoyannis 2015).

We can conceive of this as the explanatory repercussions of reading history backward (figure 1). It often is held that these problems are especially pronounced when political economists do history because they frequently subscribe to either a cyclical view of history (i.e., an emphasis on equilibria) or a teleological view (in which certain institutions create a path of unfettered progress). The first perspective tends to "freeze" history, whereas the second perspective makes history "efficient" (March and Olsen 1983). Freezing history leads scholars to ignore bounded change in which institutions are altered in a piecemeal fashion via the interaction between changing and fixed institutional aspects. A good example is what Mahoney and Thelen $(2010,16)$ refer to as "conversion" or "the changed enactment of existing rules due to their strategic between monarch and social groups. I demonstrate that by reading history backward, this research has ignored that these institutions were originally introduced by first ecclesiastical and then lay rulers in a much more contingent way, only later to develop into institutions that nobles, clergy, and townspeople could use to constrain rulers (see also Boucoyannis 2015).

However, these explanatory repercussions are not the only problematic aspects of reading history backward. Indeed, retrospective inquiry tends to affect the formulation of the problem under study, the conceptual understanding of the explanandum, and the historical sources that can be enlisted. We can think of this as the conceptual repercussions of reading history backward and, because they have not received nearly as much attention as the explanatory repercussions, they need more elaboration (figure 2).

\section{Figure 1 \\ Explanatory Repercussions of Reading History Backward}

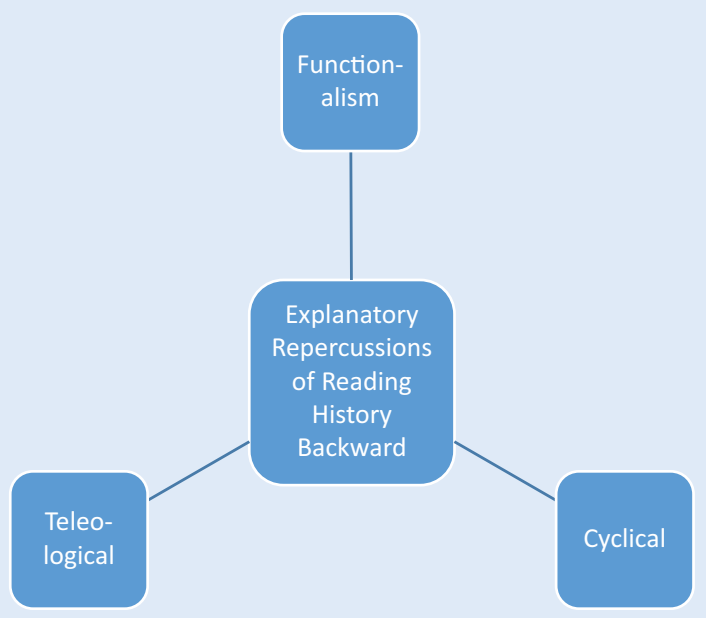




\section{Figure 2 \\ Conceptual Repercussions of Retrospective Analysis}

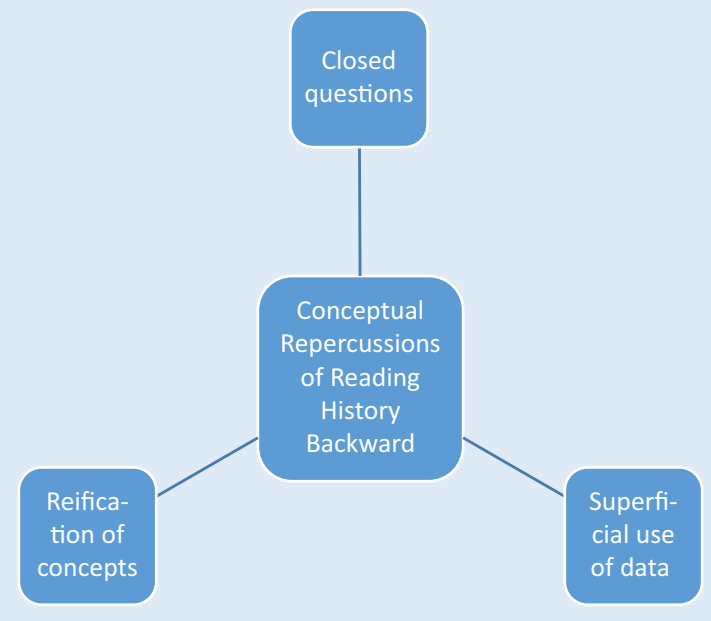

The first conceptual problem concerns the way that scholars who read history backward pose their research questions. In a genuinely historical analysis, a research question is left open in the sense that it leaves room for the unexpected. In a Popperian vein of thinking, it allows for alternative explanations to be vindicated. Retrospective questions are normally quite narrow-we might even say closed-because they take certain things for granted. This increases the risk that alternative outcomes or causal antecedents are ignored. A common warning signal is when research questions mimic or echo one another across a larger research agenda (Fischer 1970, 24-28).

The second conceptual problem concerns the definition of the phenomenon to be explained. Scholars who delve into history to explain later institutions are apt to project the definition that meaningfully characterizes later institutions back in time, often without recognizing its poor fit with the institutions from which the subsequent ones sprang. We can think of this in terms of a reification of concepts or as conceptual stretching (Sartori 1970). It is related to the explanatory problem of freezing history because it blinds researchers to the possibility that institutions evolved significantly over time-indeed, that institutions sometimes are fundamentally transformed (Mahoney and Thelen 2010).

The online appendix illustrates these two problems by showing how many of the social scientists who have recently revisited the origins and development of medieval parliaments have taken the fact that these institutions constrained monarchs as the point of departure. Scholars therefore define representative institutions as "institutions of constraints," and they ask which factors explain that rulers became constrained by these institutions. This has had two unfortunate consequences. First, it means that the definitions have a poor fit with the early phase of representative institutions, which-as historians emphasize-were institutions called at the whim of the ruler to exercise power rather than institutions that constrained rulers. Second, it has biased the answer in favor of structural explanations centered on the societal balance of power, thereby ignoring the actors' choices that first made popes and then monarchs summon representative institutions. In other words, this research agenda has frozen history by assuming that the constraining effects of parliament can be projected farther into the past than is warranted by the historical material, thereby ignoring that institutions can change incrementally.

The third conceptual problem concerns the historical data that can be enlisted in the analysis. Whereas the previous work of historians is normally the point of departure when social scientists code large- $\mathrm{N}$ datasets and carry out in-depth historical analysis (Møller and Skaaning 2018), the conceptual lens decides what type of previous historical data is relevant. By reifying concepts and freezing history, the inquiry allows large- $\mathrm{N}$ research designs based on conditional independence and uniformity of variables (Sewell 1996). These research designs foreclose the use of most of the qualitative data produced by historians because they are based on enlisting a set of variables coded in a similar-hence, relatively general-way across space and time. Scholars risk committing what has been termed the "quantitative fallacy"-that is, the idea that "facts are important in proportion to their susceptibility to quantification" (Fischer 1970, 90). This slights valuable but often nonquantifiable information about what motivated actors to create institutions and how they actually did so. As shown in the online appendix, this is illustrated by the way the new research on medieval parliaments relies overwhelmingly on quantitative data coded across long periods (i.e., 50- or 100-year intervals) and across relatively aggregate empirical units. Conversely, the abundant qualitative information historians have produced about medieval parliaments has been used only sparingly in these empirical analyses.

\section{READING HISTORY FORWARD}

For political scientists, the best remedy against these explanatory and conceptual problems-and therefore against reading history backward-is simple but time-consuming. It consists in an openminded reading of what historians have written on a particular subject. Open-minded means that we ignore our theoretical priors in general and specific hypotheses in particular and peruse the historical literature-not to find evidence for a preconceived explanation but instead to reveal new aspects of a certain empirical development. This is very much a question of forcing a certain cognitive mindset on ourselves. Berlin's (1953) famous distinction between foxes and hedgehogs—or pluralism and monism-comes to mind.

In other words, what is needed is an exploratory review of the historical literature on the subject of interest in which the work of historians is treated not only as a source of facts but also as a source of explanations. This entails a proper reading of this literature, which is why it is time-consuming. This type of reading can be described with a negative: it is the opposite of what Hexter $(1979,241)$ calls "source-mining"-that is, "the examination of a corpus of writing solely with a view to discovering what it says on a particular matter narrowly defined-going through the indexes and leafing through the pages." Thus, it requires that we thoroughly immerse ourselves in the historical literature and learn about the agreements and disagreements among historians working on a particular subject, as well as the historical context in which the developments in question occurred (Lustick 1996).

Historians, of course, have their own theoretical and methodological priors; indeed, all history is told from some vantage point, which can be either implicit or explicit, and all historical facts have in some sense been preselected (Lustick 1996; Møller 2020; Møller and Skaaning 2018). For instance, depending on whether 
historians work within a Marxist, an Annales, or a third tradition, they are likely to use different concepts and therefore select different evidence-and, in all likelihood, to reach different conclusions (Hexter 1979, 61-145). This can be exemplified by contrasting an older historical literature-drawing on Marxism-that analyzed the religious sects during the English Civil War through the analytical lens of proletarian class hostility with more recent work, which jettisons the Marxist perspective and, accordingly, finds much more diversity in the views of the "radical" groups that arguments that often characterize historiography (Lustick 1996; Møller and Skaaning 2018).

Thus, the idea is not to substitute the tendency to read history backward with a "barefoot empiricism" that sees historians as presenting consistent, noncontradictory, theoretically coherent, and uncontaminated accounts based on a representative body of data. No serious historian would accept this caricature as a valid view of what they do. However, precisely because political scientists are more constrained by their theories and their more particular expect-

\section{For political scientists, the best remedy against these explanatory and conceptual problems -and therefore against reading history backward-is simple but time-consuming. It consists in an open-minded reading of what historians have written on a particular subject.}

opposed the royalists in the 1640 s and 1650 s (Worden 2019, 19). The online appendix provides another example of how historians sometimes read history backward, centered on the Sonderweg debate on German history.

However, as Kreuzer (forthcoming, 10) states:

\begin{abstract}
What makes reading historians so enjoyable is the unconstrained nature of their narratives. Unlike social scientists, historians are far less hemmed in by epistemological priors, theoretical presuppositions, or methodological exigencies and consequently are capable of providing accounts that are nuanced, comprehensive, and, above all, attuned to changes across time.
\end{abstract}

In a word, work by historians is normally more open and forward looking than the historical analysis done by social scientists. Gaddis $(2002,56)$ presents this as the difference between the reductionist models of social scientists, which are needed "to generalize about the past in such a way as to be able to forecast the future," and the historians' ecological approach, which "gleefully proliferates variables all the time" (Gaddis 2002, 58; see also Møller 2020, 254-55). This gleeful acceptance of the complexity of the past can be frustrating for political scientists who want to understand average effects of particular variables and who have been trained to avoid overdetermined and/or eclectic explanatory accounts. However, it allows historians to keep an open mind about the possible causes of certain phenomena and the contingency of historical developments, and it is the reason that immersing ourselves in their works is such a good check on retrospection. ations, they stand to gain by broadening their perspective through an initial open-minded reading of the previous work of historians.

The online appendix shows that a more forward-looking analysis of the development of representative institutions is possible because medieval historians have already done the difficult work of providing the necessary data; political scientists simply need to process it. This open or forward-looking approach allows scholars to be present at creation, for instance, by asking why first popes and their agents (i.e., papal legates, nuncios, or archbishops) started using proctorial representation, based on Roman Law, at assemblies around $1200 \mathrm{AD}$ and why kings then quickly followed suit (Møller 2018). This open approach also enables scholars to correct mistakes that, through an older body of historical work, have made their way into social science, henceforth to be repeated without scholars actually investigating their basis. A good example is the often-repeated observation that the first genuine representative institution was summoned by King Alfonso IX in the realm of Leon in 1188 (Boucoyannis 2015, 315, fn. 86; van Zanden, Buringh, and Bosker 2012, 838). ${ }^{3}$ What we know is that Leonese townspeople attended the 1188 assembly (as they would again in 1202 and 1208) and that they in some way had been "chosen from or elected by every city" (et cum electis civibus ex singulis civitatibus) (Reynolds 2012 [2000], 108). However, it does not follow that they attended as genuine representatives of their town council (concejos). There is, in fact, no evidence that townspeople arrived as proctorial representatives based on Roman Law (Reynolds 2012 [2000], 108), the defining attribute of medieval

\section{The more general point motivating these two articles is that only brutally honest and open discussions of how we, as a profession, "do history" will enable us to do better in future work.}

Using a metaphor, the previous work of historians comprises a quarry that political scientists can mine to find the hidden gems that their theories and models disguise. After this exploratory phase, they then can use the standard tools of causal analysis to apply the theoretical arguments they have borrowed from historians against new evidence (Coppedge 2012, ch. 5). In this phase, they also will need to systematically decide which historical accounts are reliable as sources of data given the purpose at hand-and systematically factor in the range of conflicting representative institutions (see the online appendix). Furthermore, this is entirely implausible given that medieval historians now agree that the invention of proctorial representation at assemblies dates to Innocent III's and Honorius III's pontificates in the period 1198-1227 (Møller 2018).

\section{CONCLUSIONS}

As Fischer (1970, 137) notes, "[t]he fallacy of presentism is a common failing in historical writing by men who have never been 
trained in the discipline of history." The point of departure for this article is that political scientists often read history backward and that this pollutes the interpretation of historical facts. Whereas there is an agreement about one aspect of this problem-namely, that a retrospective analysis increases the risk of imputing causes from consequences-I argue that the bias induced by reading history backward is much broader than this. It narrows the way the problem is posed, it predisposes scholars to use anachronistic definitions, and it affects the type of historical data that can be enlisted. In summary, it imposes blinders on the historical inquiry.

In the often-heated debates about how political scientists "do history," this issue has been curiously neglected. It deserves recognition if political scientists are to more fully harness the insights of previous historical work in their historical analyses. On this basis, I present a simple but also time-consuming way of doing a "prospective check" on the historical analysis of political scientists-namely, to match it with the previous work of historians. More generally, scholars who want to free themselves of the shackles of retrospection are recommended to start by immersing themselves, with an open mind, in what historians have written about a particular subject before they move on to interpret the evidence with a particular explanatory model in mind-and using standard methods of causal analysis.

Finally, a proviso: In previous work, I have carried out most of the practices that this article criticizes (see the online appendix). Indeed, it is by regularly doing historical work that I now find flawed in certain respects that the problems and dilemmas discussed here and in its companion piece (Møller 2020) gradually became clear to me. Moreover, it is important to stress that the work singled out for criticism in these two articles contains numerous insights that are not compromised by the problems that I discuss. The more general point motivating these two articles is that only brutally honest and open discussions of how we, as a profession, "do history" will enable us to do better in future work.

\section{ACKNOWLEDGMENTS}

I am indebted to Marcus Kreuzer, Gerardo Munck, Derek Beach, Jonas Gejl Kaas, and Svend-Erik Skaaning for comments. Any errors are my own.

\section{SUPPLEMENTARY MATERIALS}

To view supplementary material for this article, please visit http:// dx.doi.org/10.1017/S104909652000092X. =

\section{NOTES}

1. As Fischer $(1970,136)$ further explains, the historical account is falsified by the retrospective symmetry that the scholar imposes on it: "[b]ackward projections of present phenomena so grossly distort the past that the reader receives an utterly erroneous idea of events in earlier periods, and of tendencies in his own as well."

2. I am indebted to an anonymous reviewer for suggesting this definition.

3. See the online appendix for full references.

\section{REFERENCES}

Bartolini, Stefano. 1993. “On Time and Comparative Research.” Journal of Theoretical Politics 5 (2): 131-67.

Berlin, Isaiah. 1953. The Hedgehog and the Fox: An Essay on Tolstoy's View of History. London: Weidenfeld \& Nicolson Ltd.
Boucoyannis, Deborah. 2015. "No Taxation of Elites, No Representation: State Capacity and the Origins of Representation." Politics and Society 43:303-32.

Capoccia, Giovanni, and Daniel Ziblatt. 2010. "The Historical Turn in Democratization Studies: A New Research Agenda for Europe and Beyond." Comparative Political Studies 43 (8/9): 931-68.

Coppedge, Michael. 2012. Democratization and Research Methods. Cambridge: Cambridge University Press.

Fischer, David H. 1970. Historians' Fallacies: Toward a Logic of Historical Thought New York: Harper \& Row.

Fischhoff, Baruch. 1975. "Hindsight $\neq$ Foresight: The Effect of Outcome Knowledge on Judgment under Uncertainty." Journal of Experimental Psychology: Human Perception and Performance 1 (3): 288-99.

Gaddis, John Lewis. 2002. The Landscape of History: How Historians Map the Past Oxford: Oxford University Press.

Greengrass, Mark. 2014. Christendom Destroyed: Europe 1517-1648. New York: Viking Press.

Hexter, Jack H. 1979. “The Historical Method of Christopher Hill.” In On Historians, ed. Jack H. Hexter, 227-51. London: HarperCollins.

Kreuzer, Marcus. 2010. "Historical Knowledge and Quantitative Analysis: The Case of PR Adoption in Early Democracies.” American Political Science Review 104 (2): 369-92.

Kreuzer, Marcus. Forthcoming. "Analyzing Time and History: Surveying the Tools of Comparative Historical Analysis." In The Oxford Handbook on Politics in Time, ed. Klaus Goetz.

Lustick, Ian S. 1996. "History, Historiography, and Political Science: Multiple Historical Records and the Problem of Selection Bias." American Political Science Review 90 (3): 605-18.

Mahoney, James, and Kathleen Thelen. 2010. "A Theory of Gradual Institutional Change." In Explaining Institutional Change: Ambiguity, Agency, and Power, ed. James Mahoney and Kathleen Thelen, 1-37. Cambridge: Cambridge University Press.

Mahoney, James, and Kathleen Thelen (eds.). 2015. Advances in ComparativeHistorical Analysis. Cambridge: Cambridge University Press.

March, James G., and Johan P. Olsen. 1983. "The New Institutionalism: Organizational Factors in Political Life." American Political Science Review 78 (3): 734-49.

Møller, Jørgen. 2018. "The Ecclesiastical Roots of Representation and Consent.” Perspectives on Politics 16 (4): 1075-84.

Møller, Jørgen. 2020. "Feet of Clay? How to Review Political Science Papers that Make Use of the Work of Historians." PS: Political Science \& Politics 53 (2): 253-57.

Møller, Jørgen, and Svend-Erik Skaaning. 2018. "The Ulysses Principle: A Criterial Framework for Reducing Bias When Enlisting the Work of Historians." Sociological Methods \& Research. Available at https://doi.org/10.1177/ 0049124118769107.

Pierson, Paul. 200o. "Increasing Returns, Path Dependence, and the Study of Politics." American Political Science Review 94 (2): 251-67.

Rasmussen, Magnus, and Jonas Pontusson. 2017. "Working-Class Strength by Institutional Design? Unionization, Partisan Politics, and Unemployment Insurance Systems, 1870 to 2010." Comparative Political Studies. Available at https://doi.org/10.1177/0010414017710269.

Reynolds, Susan. 2012 [200o]. "Government and Community." In The Middle Ages without Feudalism: Essays in Criticism and Comparison on the Medieval West, ed. Susan Reynolds, 86-112. Farnham, UK: Ashgate Publishing.

Sartori, Giovanni. 1970. "Concept Misformation in Comparative Politics." American Political Science Review 64 (4): 1033-53.

Sewell, William H. 1996. "Three Temporalities: Toward an Eventful Sociology.” In The Historic Turn in the Human Sciences, ed. Terence J. McDonald, 245-80. Ann Arbor: The University of Michigan Press.

Skocpol, Theda, and Margaret Somers. 198o. "The Uses of Comparative History in Macrosocial Inquiry." Comparative Studies in Society and History 22 (2): 174-97.

Tilly, Charles. 1975. The Formation of National States in Western Europe. Princeton, NJ: Princeton University Press.

Tilly, Charles. 1984. Big Structures, Large Processes, Huge Comparisons. New York: Russell Sage Foundation.

van Zanden, Jan L., Eltjo Buringh, and Maarten Bosker. 2012. "The Rise and Decline of European Parliaments, 1188-1789." The Economic History Review 65 (3): 835-61.

Worden, Blair. 2019. "Novel and Naughty." London Review of Books. September 26 19-22. 